\title{
INVENTAR UMA SUNNAH: \\ o ESTADO ISLÂMICO, SALAFISMO E INOVAÇÃO
}

\author{
Gilvan Figueiredo Gomes (D) $\nabla$
}

DOT Digital Group

\section{Gilvana de Fátima Figueiredo Gomes iD $\nabla$ \\ Universidade Estadual Paulista Júlio de Mesquita Filho}

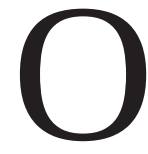

artigo analisa a atuação midiática do Estado Islâmico na segunda década do século XXI, tendo como eixo interpretativo os processos de hibridação do movimento que, sustentado e sustentando um profundo sectarismo religioso oriundo do salafismo, expressou seus projetos em suportes midiáticos característicos da tecnologia ocidental. Tais processos são evidenciados como mostra da mobilidade cultural do salafismo histórico e do Estado Islâmico, posto que ambos são capazes de, em função das circunstâncias, entrar e sair de sua base teórica e se apropriar de inovações tecnológicas.

Com a intenção de oferecer uma proposta de interpretação à atuação do grupo, o texto privilegia as discussões elaboradas no âmbito dos estudos culturais em diálogo com investigações interdisciplinares que tomam a jihad como objeto de análise. Os conceitos mobilizados têm, unicamente, a intenção de estimular reflexões que abordem o Estado Islâmico como um projeto histórico pautado na reconversão de elementos culturais; diante de um tema complexo e multifacetado, não houve a pretensão encerrar o debate.

$\mathrm{O}$ artigo está dividido em quatro partes. Na primeira, abordam-se brevemente discussões elaboradas no campo dos estudos culturais. $\mathrm{Na}$ segunda parte, avaliam-se, a partir da bibliografia, as manifestações salafistas e sua pretensa imutabilidade com ênfase nas contingências 
que desafiaram a solidez de tais projetos. Na sequência, examina-se a reconversão de tecnologias contemporâneas por grupos identificados com o salafismo jihadista. Ao final, o trabalho sugere que os processos de hibridização promovidos pelo Estado Islâmico não foram o cerne dos questionamentos teológicos levantados por opositores do grupo.

\section{Notas introdutórias para uma proposta de reflexão sobre as culturas}

O processo de globalização experimentado entre as décadas finais do século XX e iniciais do XXI evidenciou os limites do aparato conceitual constituído desde o século XIX para avaliar objetos culturais. ${ }^{1}$ Em linhas gerais, pode-se afirmar que a progressiva ampliação da noção de cultura levou, em um primeiro momento, ao reconhecimento epistemológico da diversidade de práticas e representações que poderiam ser descritas como culturais. ${ }^{2}$ Avaliada, inicialmente, como operação coletiva que fornece

1 Néstor García Canclini, Culturas híbridas: estratégias para entrar e sair da modernidade, São Paulo: Edusp, 2008. Nestor García Canclini, assim como Homi Bhabha, Serge Gruzinski e Zygmunt Bauman apresentam reflexões sobre as dinâmicas da globalização e sua interação com comunidades e culturas vistas como tradicionais, estáveis, fixas e ontológicas. Tais autores apontam para a instabilidade característica desses grupos e indicam questões pertinentes que nos ajudaram a construir o artigo; tais autores, assim como o artigo, não pretendem oferecer uma apreensão totalizadora do islã, do salafismo ou de quaisquer outros fenômenos culturais.

2 Peter Burke, O que é história cultural? Rio de Janeiro: Zahar, 2005. Ao final da obra, Burke apresentou o que considera os três problemas fundamentais da Nova História Cultural (NHC): a definição de cultura, os métodos a serem seguidos na NHC e o perigo da fragmentação. Quanto à noção de cultura, Burke defende que, se até pouco tempo atrás era possível falar de história social e história cultural, hoje tais concepções estão de tal forma imbricadas que seria mais interessante pensar em um gênero híbrido, o que já coloca a necessidade de vários métodos de análise. Sobre a fragmentação, Burke reconhece a dificuldade de unificar as características culturais, principalmente porque a cultura é uma força que age a favor da fragmentação. Em vez de nadar contra a cultura, portanto, Burke sugere que historiadores tomem a fragmentação como objeto de análise, observando os encontros produzidos nas fronteiras culturais e superando a concepção de cultura como um sistema fixo. Além de Peter Burke, reflexões sobre as transformações no conceito de cultura podem ser encontradas em 
organicidade aos agrupamentos humanos, as culturas subsidiaram a construção de limites identitários dentro dos quais certos recursos, comportamentos, práticas e representações são considerados legítimos. Conforme destaca Zygmunt Bauman: “Os conceitos de construção de identidade e de cultura nasceram juntos, e não podia ter sido de outra forma”. ${ }^{3}$ A multiculturalidade ensejou o reconhecimento político de alguns grupos identitários, e, estimulou outros à luta. ${ }^{4}$ Mobilizados por argumentos vários (território, religião, língua), muitos desses grupos recrutam eventos e personagens do passado para afirmarem seus projetos, articulando-os a noções, mais ou menos definidas, de tradição. ${ }^{5}$ Ao mesmo tempo, como estão inseridos em processos de trocas (materiais e simbólicas) em âmbito global, registram-se diferentes tipos de apropriação cultural. ${ }^{6}$

Serge Gruzinski, que investigou as trocas culturais ocorridas no continente americano a partir do século XVI, ressaltou que algumas pesquisas são reticentes em abordar tais objetos, vistos como sinal de descaracterização de uma cultura essencializada. ${ }^{7}$ Há, ainda, avaliações que reduzem essas apropriações a uma ideia difusa de passividade, a partir da qual agentes e instituições que operam recursos reconvertidos são tomados como vítimas de um imperialismo cultural, emanado de centros ocidentais. ${ }^{8}$ Outra é a abordagem de autores ligados aos estudos culturais

Maria Elisa Cevasco, Dez lições sobre estudos culturais, São Paulo: Boitempo, 2003 e Terry Eagleton, A ideia de cultura, São Paulo: Editora Unesp, 2003.

3 Zygmunt Bauman, "From Pilgrim to Tourist - or a Short History of Identity" in Stuart Hall e Paul du Gay (orgs.), Questions of Cultural Identity (Londres: Sage, 1996), p. 19.

4 “A identidade cultural anda de mãos dadas com a política cultural. [...] Numa sociedade multicultural as diferenças culturais devem ser respeitadas, até mesmo estimuladas”, Adam Kuper, Cultura: a visão dos antropólogos, Bauru: Edusc, 2002, p. 299.

5 Joyce Apleby, Lynn Hunt e Margaret Jacob, “Telling the Truth About History” in Fernando Novais e Rogerio Forastieri da Silva (orgs.), Nova história em perspectiva (São Paulo: Cosac Naify, 2011), p. 364.

6 Néstor García Canclini, A globalização imaginada, São Paulo: Iluminuras, 2007.

7 "Fenômenos sociais e políticos, as mestiçagens manobram, na verdade, com tal número de variáveis que confundem o jogo habitual dos poderes e das tradições, escapolem das mãos do historiador que as perseguem ou são menosprezadas pelo antropólogo amante de arcaísmos, de ‘sociedades frias’ ou de tradições autênticas”, Serge Gruzinski, O pensamento mestiço, São Paulo: Companhia das Letras, 2001, p. 304.

8 Canclini, Culturas híbridas. 
que avaliam a cultura da perspectiva da dinamicidade e enfrentam o desafio teórico e metodológico de investigar esses objetos. Da busca por uma essência da cultura passa-se, não sem esforço, ao reconhecimento de que as culturas estão - e sempre estiveram - em um processo de fluidez, de embates, encontros e, principalmente, sendo estrategicamente utilizadas para atender a interesses contingentes. Recursos analíticos como a noção conceitual de hibridação ajudam a interpretar "processos socioculturais nos quais estruturas ou práticas discretas, que existiam de forma separada, se combinam para gerar novas estruturas, objetos e práticas", ${ }^{9}$ cujo funcionamento ocorre:

de modo não planejado ou [como] resultado imprevisto de processos migratórios, turísticos e de intercâmbio econômico ou comunicacional. Mas frequentemente a hibridação surge da criatividade individual e coletiva. Não só nas artes, mas também na vida cotidiana e no desenvolvimento tecnológico. Busca-se reconverter um patrimônio (uma fábrica, uma capacitação profissional, um conjunto de saberes e técnicas) para reinseri-las em novas condições de produção e mercado. ${ }^{10}$

Com base nessas reflexões, fenômenos recentes, como o Estado Islâmico, podem ser examinados de forma a restituir a complexidade característica das culturas e a superar interpretações orientalistas e reducionistas que tomam o movimento como estritamente violento, fundamentalista e atrasado. $^{11}$

9 Canclini, Culturas híbridas, p. XIX.

10 Canclini, Culturas híbridas, p. XXII, grifo no original.

11 Álex Vicente, "Por que o Estado Islâmico odeia a França”, El País ש; Loretta Napoleoni, fênix islamista: o Estado Islâmico e a reconfiguração do Oriente Médio, Rio de Janeiro: Bertrand Brasil, 2016. 


\section{Salafismos, hibridização e o porvir}

Em 2001, com a invasão do Afeganistão por forças militares norte-americanas, a cidade de Qandahar criou um cemitério exclusivo para os chamados "visitantes estrangeiros", termo utilizado para designar combatentes de outros países que se uniram à resistência local. Ao analisar tal processo, o antropólogo estadunidense Darryl Li, em Taking the Place of the Martyrs: Afghans and Arabs under the Banner of Islam, distinguiu uma aparente ironia: como em outras cidades do país, os moradores locais começaram a visitar as tumbas desses combatentes forasteiros para pedir intercessões; um dos entrevistados, citado por $\mathrm{Li}$, alegou que os mortos deveriam estar se revirando em seus túmulos, já que em vida foram contrários a essas práticas de adoração a mártires. ${ }^{12} \mathrm{~A}$ ironia está no fato de que a adoração de túmulos é uma prática sufista e regional, característica de comunidades islamizadas próximas à Ásia, ao passo que veteranos que participaram da fundação de organizações como al Qa'idah ${ }^{13}$ e Estado Islâmico julgam esses comportamentos como bida', ou seja, inovações

12 Darryl Li, “Taking the Places of Martyrs: Afghans and Arabs under de Banner of Islam”, Arab Studies Journal, v. 20, n. 1 (2012), pp. 12-39. O indício de hibridização não se restringe à adoração, mas se estende à ideia de mártires. A martirologia no islã é um fenômeno xiita, centrado na morte do neto do profeta, Husayn Ibn Ali, em 680, rememorado anualmente no ritual da Ashura. No sunismo, especialmente em círculos salafistas, a martirologia ganha destaque a partir da publicação de The Signs of ar-Rahmaan in the Jihad of Afeganistan (1983), um compilado de sinais de favorecimento divino à causa dos muçulmanos. O livro, assinado por Abdallah 'Azzam, um dos principais teóricos jihadistas dos anos 1980, relata corpos emanando perfume e sem se decompor. David B. Cook, "Contemporary Martyrdom: Ideology and Material Culture” in Thomas Hegghammer (org.), Jihadi Culture: The Art and Social Practices of Militant Islamists (Cambridge: Cambridge University Press, 2017), pp. 151-170. É importante ressaltar que a martirologia é presente no sunismo, entretanto, com o objetivo de recrutar, 'Azzam introduziu o martírio como uma expectativa ou objetivo para os fiéis.

13 O leitor ou a leitora observará diferenças em palavras transliteradas. Preconiza-se, neste trabalho, a grafia corrente nas fontes, o que nos aproxima do léxico dos estudos especializados. Nesse sentido, usamos al Qa'idah, em vez de al Qaeda, e Shar'iah, em detrimento de xaria. 
religiosas que deveriam, por isso mesmo, ser desestimuladas. ${ }^{14} \mathrm{O}$ que as orações em cemitérios de mártires sugerem, segundo Li, são trocas culturais que, ao longo do tempo, fizeram do islã um vetor de convergência para práticas outrora divergentes. ${ }^{15}$

Umas das organizações mais hostis à ideia de bida' foi o Estado Islâmico. Autoproclamado califado em 2014, ${ }^{16}$ a organização tem raízes na atuação de Abu Musab al-Zarqawi (1966-2006) durante a Guerra do Iraque (2003). ${ }^{17}$ Até sua versão mais conhecida, passou por diferentes encar-

14 O Islã, enquanto fenômeno histórico, não pode ser apreendido de modo ontológico e as definições variam a depender do sujeito ou instituição que se apropriam dessas práticas e representações, as quais, para que sejam apropriadamente debatidas, exigiriam um escopo distinto para o artigo. Cumpre pontuar que pensadores(as) que compartilham da fé islâmica manifestam posicionamentos opostos. Em primeiro lugar, salafistas têm como fundamento definir quem são os muçulmanos e quem são os desviados. Segundo, após 11 de setembro de 2001, representantes do islã, como o professor de al Azhar, Ahmed al-Dawoody, questionam a legitimidade religiosa de grupos como a al Qa'idah e o Estado Islâmico dada sua estratégia de praticar atos violentos. Por outro lado, a muçulmana Irshad Manji defende que os fiéis devem compreender o papel de sua religião nos atos dessas organizações. Essas duas posturas, mesmo islâmicas, são diametralmente opostas e evidenciam quão complexo poder ser falar sobre o islã; ao mesmo tempo, indicam como pode ser problemático supor que um autor islâmico estaria mais abalizado a refletir sobre o Islã. As oposições entre os dois autores citados podem ser verificadas em: Ahmed al-Dawoody, "ISIS and its brutality under Islamic Law”, Kansai University Review of Law and Politics, v. 2, n. 36 (2015), pp. 101-117 e Irshad Manji, The Trouble with Islam Today: A Muslim's Call for Reform in her Fatith, Toronto: Random House, 2004.

15 Li, "Taking the Places of Martyrs".

16 Califados são os territórios de domínio do califa. Muhammad não estabeleceu critérios para sua sucessão e, quando faleceu em 632, teve início um profundo debate sobre o Khalifah Rasulullah - sucessor do Mensageiro de Deus. O califa deve aplicar o islã em seus domínios e seguir os ensinamentos de Muhammad. Dada a amplitude da religião e de suas interpretações, a legitimidade do sucessor não é um ponto pacífico; a cisão entre sunitas e xiitas, com raízes na escolha do primeiro califa, é modelar das tensões que o título invoca. Para uma análise aprofundada, ver: Peter Demant, O mundo muçulmano, São Paulo: Contexto, 2013.

17 Nascido Ahmad Fadeel al-Nazal al-Khalayleh em 1966, notabilizou-se por seus métodos brutais, que lhe renderam a alcunha de "Shaky dos Chacinadores". Após uma juventude marcada pela criminalidade, al-Zarqawi (em referência a sua cidade natal, Zarqa) tornou-se religioso nos anos 1980. Combateu no Afeganistão entre 1989 e 1992, e após retornar para a Jordânia, esteve preso entre 1994 e 1999. Depois do 11 de setembro de 2001, al-Zarqawi partiu para o Iraque, fundando no país a Tawhid wal jihad - Monoteísmo e Jihad -, grupo responsável por ataques contra militares estadunidenses, decapitações de prisioneiros estrangeiros e por investidas contra a população xiita, instigando, assim, a guerra civil. Em 2006, al-Zarqawi foi morto 
nações e nomes, se aproximando e distanciando de outras organizações ao longo do tempo. Após infiltrar-se na Síria em 2013, o então combalido grupo jihadista capitalizou as condições do conflito iniciado em 2011, se fortaleceu e retornou ao Iraque para se consolidar como a organização mais bem-sucedida da segunda década do século XXI. Com o anúncio do califado, o Estado Islâmico lançou uma revista chamada Dabiq, que, de acordo seu primeiro editorial, é focada em monoteísmo, jihad, o método apropriado de fé, imigração e união. ${ }^{18}$ A postura do Estado Islâmico em relação às práticas divergentes das suas está ligada ao salafismo. O nome desse movimento islâmico vem da expressão honorífica al Salaf al Salih os ancestrais piedosos -, utilizada para designar as três primeiras gerações de muçulmanos. Salaf se refere unicamente a sujeitos que aprenderam o islã diretamente com o profeta, razão pela qual são reconhecidos como corretamente guiados. ${ }^{19}$ Ao longo da história muçulmana, outros nomes se associaram ao termo por terem adotado um comportamento que restringia, ao extremo, inovações religiosas. Exemplares, nesse sentido, são os teóricos reformistas Ahmad Ibn Hanbal (780-855) e Taqi al-Din Ibn Taymiyyah (1263-1328), conhecidos como Madhhab al Salaf (ao modo dos Salafs $)^{20}$. Por sua vez, o salafiyya - salafista - é um movimento relati-

pelos EUA com apoio de forças iraquianas. Loretta Napoleoni, Insurgent Iraq: Al Zarqawi and the New Generation, London: Seven Stories Press, 2005.

18 "Foreword", Dabiq: Return of the Khilafah, n. 1, 5 jul. 2014 (Ramadan 1435 AH) ש. Os números de Dabiq podem ser acessados mediante confirmação de interesse acadêmico e registro do usuário.

19 “Corretamente guiados” é uma expressão corrente no vocabulário religioso sunita e entre os membros dos grupos aqui analisados. Corresponde ao período dos Rashidun, ou Califas Corretamente Guiados (632-661). Os Rashidun são Abu Bakr (573-634), Umar (584-644), Uthman (579-656) e Ali (601-661).

20 Abu 'Abdillah Ahmad Ibn Muhammad Ibn Hanbal Ash-Shaybani, de Bagdá, foi o fundador da Escola hanbalita. Os hanbalitas se destacam pela oposição a qualquer forma de interpretação do texto sagrado, sob o receio de distorcer as palavras divinas. O comprometimento com o Qur'an pressupõe que o texto não foi criado, mas sim revelado e, nesse sentido, qualquer consideração que entre em conflito com o texto sagrado deve ser desconsiderada. Ibn Hanbal influenciou leituras sectárias do islã, incluindo Ibn Taymiyyah, Ibn Wahhab (1702-1792), al Qa'idah e o Estado Islâmico. Joas Wagemakers, "Salafism: Generalisation, Conceptualisation and Categorisation" in Magnus Ranstorp (org.), Contextualising Salafism and Salafi Jihadism (Copenhagen: National Center for Forebyggelse af Ekstremise, 2020), pp. 21-36. 
vamente mais recente, geralmente associado a pensadores modernistas no Cairo no fim do século XIX e, já no século XX, a formas mais sectárias de sunismo manifestadas após 1970. Apesar da cadeia de referências em comum, os três termos apontam para fenômenos diferentes.

Em suma, salafistas são indivíduos ou grupos que tentam emular cotidianamente os Salafs em todos os aspectos da vida humana. ${ }^{21}$ Essa aqidah, ou crença, se manifesta por meio de uma noção restritiva de tawhid que, por sua vez, designa um conceito de unicidade divina: Allah é, dessa perspectiva, o único criador do universo e aquele do qual emana todo o poder. Essa noção, por certo, pode ser encontrada em outras religiões monoteístas, mas há particularidades no salafismo. Qualquer associação entre humanos e deus é considerada politeísmo, o mesmo se aplica a expressões que corporificam Allah (como, por exemplo, “os olhos de deus” ou “a mão divina”). ${ }^{22}$ Inovações religiosas são rechaçadas, incluindo as quatro escolas de jurisprudência sunita. ${ }^{23}$ As únicas

Taqi al-Din Ibn Taymiyyah viveu na cidade de Damasco e é um dos acadêmicos mais apropriados pelo salafismo. Escritor prolixo e polemista, Ibn Taymiyyah se dedicou a combater toda e qualquer inovação no islã. Em 1303, com o Levante (região dos atuais Síria e Líbano) sob domínio mongol, o acadêmico emitiu um ordenamento jurídico alegando que combater os governantes era uma obrigação dos muçulmanos. Para tanto, Ibn Taymiyyah fez o Takfir, ou seja, excomungou o então governante, Mahmud Ghazan (1271-1304), que havia se convertido ao islã em 1295. Para uma análise mais consistente dos escritos do damasceno, ver: Jon Hoover, Ibn Taymiyya's Theodicy of Perpetual Optimism, Leiden: Koninklijke Brill, 2007.

21 Wagemakers, "Salafism".

22 Os atributos e nomes de Allah, ou al-asma' wal-sifat, mobilizam um profundo debate. O Qur'an menciona antropomorfismos, mas, ao mesmo tempo, estabelece que não há similaridades entre o criador e suas criaturas. Entre os séculos VIII e X, um grupo de acadêmicos especulativos conhecidos como al-mu'tazilah propôs que o texto sagrado utilizava metáforas para se tornar inteligível aos humanos. Tal posição foi rechaçada por Ibn Hanbal, Ibn Taymiyyah e, contemporaneamente, é negada por salafistas. Para estes, os seres humanos devem simplesmente aceitar que não são capazes de compreender holisticamente o Qur'an. Especulações dessa monta foram denunciadas como tentativas de reduzir a palavra divina à lógica mundana. Hoover, Ibn Taymiyya's theodicy of perpetual optimism; Quintan Wiktorowicz, "Anatomy of the Salafi Movement”, Studies in Conflict \& Terrorism, v. 3, n. 29 (2006), pp. 207-239.

23 Com o fim do Rashidun, em 661, acadêmicos do mundo muçulmano empreenderam projetos de sistematizar a interpretação da religião. As Madhhab al-Fiqh, escolas de jurisprudência, no sunismo são Hanafi, Maliki, Shafi e Hanbali. George Makdisi, “The Significance of the Sunni Schools of Law in Islamic Religious History”, International 
fontes de conhecimento consideradas autênticas são o Qur'an (o livro sagrado), a Sunnah - leia-se a tradição acessada por meio dos Ahadiths (conjunto de narrativas sobre a vida do Profeta) - e o consenso dos al Salaf al Salih.

Apesar da pretensa rigidez, pesquisadores têm evidenciado contingências desenvolvidas a partir de interpretações do presente à luz do passado. Assim, pode-se afirmar que, embora o salafismo reúna agentes que adotam uma postura a-histórica, no sentido de negar inovações religiosas motivadas pelo processo histórico, o itinerário desses grupos revela indícios de hibridação. A proposta de divisão e transformação mais conhecida (e citada) é de Quintam Wiktorowicz, que sugere que os salafistas apresentam sempre o mesmo credo (aqidah), mas divergem nos métodos (manhaj) utilizados. Essa diferença de métodos se manifesta, precisamente, nas formas de se relacionar com os poderes políticos estabelecidos. ${ }^{24}$ Os critérios adotados por Wiktorowicz podem ser associados à noção de teologia pública. Geralmente aplicada à análise de manifestações cristãs, a teologia pública pode ser definida como as formas de inserção da religiosidade no espaço público. No esquema teórico de Nukhet Sandal, as teologias públicas têm quatro dimensões: (i) substantiva, ou seja, o catalisador para a entrada da religiosidade no espaço público; (ii) espiritual, o conjunto de signos e dogmas que conduzem a religiosidade e que podem ser mobilizados; (iii) temporal; e (iv) espacial. ${ }^{25}$ Em vista dessas dimensões, é possível compreender como sujeitos

Journal of Middle East Studies, v. 10, n. 1, (1979), pp. 1-8. Cada uma das escolas desenvolveu métodos específicos que não cabem no escopo deste artigo, mas vale evidenciar que os salafistas negam o direito a tentativas de interpretação. É importante ressaltar que o reconhecimento a Ibn Hanbal não se estende a todos os acadêmicos que se associam a sua madhhab. Nesse sentido, poderíamos afirmar que os salafistas se conectam ao líder, mas não à corrente desenvolvida a partir de seus escritos.

24 Wiktorowicz, "Anatomy of the Salafi Movement”.

25 Nukhet Ahu Sandal, "The Clash of Public Theologies? Rethinking the Concept of Religion in Global Politics”, Alternatives: Global, Local, Political, v. 37, n. 1 (2012), pp. 66-83. 
que compartilham a mesma fé podem se reconhecer mutuamente, mas discordar frontalmente em temas específicos.

Em uma perspectiva similar, Wiktorowicz diferencia três grupos. O primeiro é o dos puristas, que, como o próprio nome sugere, têm o objetivo de purificar o islã e reúne sujeitos e grupos que preconizam o proselitismo em detrimento da atuação política. Para o autor, o principal exemplo de puristas são os ulamas sauditas, já que a estabilidade do regime e seus profundos laços com o wahhabismo fortaleceram um estrato de acadêmicos com preocupações estritamente teológicas. ${ }^{26}$ As universidades islâmicas da Arábia Saudita foram o celeiro desses acadêmicos em boa parte do século XX. Contudo, a partir da década de 1960, o reino recebeu vários intelectuais egípcios que fugiam da perseguição nasserista e foram alocados como professores em instituições de ensino saudita, disseminando um islã politicamente engajado.

Surgia, assim, o segundo grupo, identificado por Wiktorowicz como salafistas políticos. De forma um tanto pejorativa, esses sujeitos também são chamados de Ikhawnistas, referência à Irmandade Muçulmana (Ikhwan al Muslimin), fundada em 1928 por Hasan al-Banna. A Irmandade é, e foi, altamente engajada da perspectiva política, sendo vital para o fim da monarquia no Egito e elegendo, inclusive, um presidente em 2012. ${ }^{27}$ A última divisão salafista corresponde aos jihadistas, grupo que, segundo o autor, teve origem na Guerra do Afeganistão (1979-1989). Naquela ocasião, a invasão de um país muçulmano por forças ateístas uniu grupos

26 Wahhabismo se relaciona ao reformismo ultraconservador de Muhammad Ibn Abd al-Wahhab (1703-1792), pautado na ideia sectária de tawhid. O clã Saud forjou uma aliança com al-Wahhab e seus seguidores com o objetivo de controlar a Península Arábica, o que se concretizou efetivamente 1932. Madawi al Rasheed, "Divine Politics Reconsidered: Saudi Islamists on Peaceful Revolution”, Middle East Centre Paper Series, v. 7, n. 3, (2015), pp. 1-18 ש.

27 Em sua quase centenária história, a Irmandade Muçulmana apresentou posturas diferentes, mantendo como característica sua atuação pública focada em processos educacionais. Ver: Tommy Larsson, "The Islamist Ideology of Hassan al-Banna and Sayyid Qutb: A Comparative Analysis”, Dissertação (Mestrado em História), University of Oslo, 2017. Thomas Hegghammer, The Caravan: Abdallah 'Azzam and the Rise of the Global Jihad, Cambridge: Cambridge University Press, 2020. 
com objetivos locais em torno de um inimigo comum. Após dez anos de conflito, o saldo foi a vitória dos jihadistas contra a União Soviética e a sensação de que seria possível usar a experiência em outros lugares do mundo. ${ }^{28}$ Amplamente citado, Wiktorowicz não escapa de algumas críticas dentro do campo de estudos jihadistas. Joas Wagemakers, por exemplo, estabelece cinco linhas de oposição. ${ }^{29} \mathrm{~A}$ primeira diz respeito ao uso da manhaj (método) como ponto de divergência. Para o historiador holandês, o texto de Wiktorowicz carece de uma definição precisa de manhaj, o que gera usos conflitantes da palavra “método” - ora como conceito, ora como substantivo. Em decorrência dessa primeira incorreção, há uma redução do conceito de manhaj ao ativismo político, que configura o segundo equívoco.

Terceiro, o texto de Wiktorowicz é centrado na experiência saudita. Stéphane Lacroix advoga que o reino é bastante singular. Segundo o autor, o próprio processo de formação da Arábia Saudita possibilitou a delimitação de um campo público e político, liderado pelos Saud, e um campo teológico, controlado pelos ulamas. ${ }^{30}$ Wagemakers não se opõe às conclusões de Wiktorowicz, mas defende, alinhado a Lacroix, que em outros países da região as fronteiras entre o público e o religioso são turvas ou inexistentes. Nesse sentido, o autor afirma que, em outros contextos históricos, as trajetórias “jihadistas” e "políticas” assumem outras características.

O quarto ponto é que o "purismo" utilizado para identificar o primeiro grupo poderia ser aplicado aos demais, afinal, engajados e jihadistas não deixam de ser puristas. Além disso, Wagemakers sugere que se a forma de interação com o poder estabelecido é o critério, então

28 Wiktorowicz, “Anatomy of the Salafi Movement”.

29 Joas Wagemakers, "Revisiting Wiktorowicz: Categorising and Defining the Branches of Salafism” in Francesco Cavatorta e Fabio Merone (orgs.), Salafism After the Arab Awakening: Contending with People's Power (London: Hurst \& Company, 2017), pp. 119-135.

30 Stéphane Lacroix, Awakening Islam: The Politics of Religious Dissent in Contemporary Saudi Arabia, Cambridge: Harvard University Press, 2011. 
seria mais apropriado utilizar o termo "quietista". ${ }^{31}$ E, por fim, assumir como divergência apenas o manhaj olvida conflitos em torno de conceitos teológicos, cujo principal exemplo é o takfir, espécie de excomunhão. ${ }^{32}$

Wagemakers indica diferenças para além do ativismo político, mas, por ser o aspecto mais evidente de divergência, compreende que pode ser um ponto de partida para avaliações dos grupos salafistas. Sugere, dessa forma, subdivisões dentro das três categorias. Os quietistas seriam divididos em três grupos: (i) os leais aos regimes em que estão inseridos, mas ausentes do debate público; (ii) os que procuram se abster de qualquer participação política; e (iii) os propagandistas, que defendem teologicamente o regime. Os salafistas políticos seriam subcategorizados entre os (i) que têm pretensões no aparato estatal; (ii) os que se valem de cargos de poder para pregar; e (iii) os ativos politicamente, mas sem participar dos sistemas estabelecidos. ${ }^{33}$

Por fim, os jihadistas podem ser segmentados em outros três agrupamentos: (i) os revolucionários, também chamados de jihadistas locais (caso do Grupo Islâmico Armado da Argélia - GIA), posto que seu objetivo é derrubar os regimes em que estão inseridos; (ii) os jihadistas globais, como a al Qa’idah, cujo inimigo é o ocidente imperialista; e (iii) jihadistas do califado, notadamente o Estado Islâmico, que buscam

31 Note-se que, no clássico A ética protestante e o espírito do capitalismo, o mesmo termo indica uma espécie de comportamento conformista. Apesar de não citar diretamente Max Weber, o uso feito por Wagemakers do termo quietista tem sentido similar, posto que se refere a agentes ou grupos que se negam a fazer intervenções públicas de cunho político. Max Weber, A ética protestante e o espírito do capitalismo, São Paulo: Companhia das Letras, 2004, p. 150.

32 Os debates em relação ao Takfir evocam o objetivo por trás da prática. Com o desenvolvimento do pensamento jihadista, teóricos poderiam declarar infiel uma pessoa ou grupo e, a partir desse momento, derramar o seu sangue torna-se permitido. Há, no bojo do takfir, definições restritas e essencializantes do que é o islã e o que define um fiel. Ver: Mansour Salim Alshammari, “Takfir and Terrorism: Historical Roots, Contemporary Challenges and Dynamic Solutions. With Especial Reference to al-Qa'ida and Kingdon of Saudi Arabia”, Tese (Doutorado em Filosofia), The University of Leeds, 2013.

33 Wagemakers, "Salafism”. 
construir um novo ator político ignorando as fronteiras atuais. ${ }^{34}$ Ao considerar os jihadistas do califado, Wagemakers evidencia um intermeio à ideia de global e local, pois avalia o Estado Islâmico como um grupo que age, concomitantemente, contra grupos locais e grupos globais.

Fawaz Gerges analisa a globalização da jihad e indica que tal processo foi inaugurado com o episódio de formação da al Qa’idah (1989), tendo como apogeu o 11 de setembro de 2001. Para o autor, a globalização da jihad é fruto de uma aliança entre o salafismo saudita (representado por Usamah Ibn Ladin - 1957-2011) e o ativismo político egípcio (encarnado por Ayman al-Zawahiri). ${ }^{35}$ Este último seria a personificação da transformação, já que tinha uma trajetória intelectual e política ligada à oposição aos regimes militares do Egito - al-Zawahiri foi um dos muitos presos após a morte do presidente Sadat em 1981. O argumento de Gerges é interessante na medida em que o autor mostra que a mudança de paradigma proposta por Zawahiri e, principalmente, por Ibn Ladin gerou conflitos internos dentro do movimento jihadista e não significou uma mudança pacífica. ${ }^{36}$

Outro autor que se dedica a essa transformação é Thomas Hegghammer. $\mathrm{O}$ pesquisador norueguês, um dos principais nomes dos estudos de jihad, se alinha a outras tentativas de estabelecer marcadores com a intenção de evitar leituras homogêneas das diferentes organizações, mas salienta que, dada a dinâmica do jihadismo, qualquer limite analítico pode ser transposto. $\mathrm{O}$ autor menciona o hibridismo teológico, mas se atém ao que chama de "preferências políticas", cujo argumento central é que, após a Guerra do Iraque, as definições de inimigo das organizações jihadistas se embaralharam e complexificaram o movimento. ${ }^{37}$

34 Wagemakers, "Salafism".

35 Fawaz Gerges, The Far Enemy: Why Jihad Went Global, Cambridge: Cambridge University Press, 2005.

36 Gerges, The Far Enemy.

37 Thomas Hegghammer, “The Ideological Hybridization of Jihadi Groups”, Current Trends in Islamist Ideology, v. 9, n. 1 (2009), pp. 26-45. 
Hegghammer é cuidadoso, pois afirma que, até 2003, as definições de inimigos não eram estáticas, mas apresentavam pontos relativamente bem delimitados. $\mathrm{O}$ autor sugere quatro possíveis razões que favoreceram a hibridização. A primeira diz respeito aos efeitos locais de políticas empregadas no pós 11 de setembro, quando o sentimento anti-Estados Unidos e as denúncias de cumplicidade dos governos locais fizeram desses elementos, aparentemente opostos, duas faces de um mesmo inimigo. A segunda é a transformação dos meios de comunicação: a popularização da internet somada ao sucesso da al Qa'idah fomentou uma tendência a incluir o discurso global no programa, para atrair a atenção de eventuais apoiadores ou da mídia internacional. A terceira razão para a hibridização sugere que tensões internas, sobre questões de ordem pragmática ou teológica, fariam parte dos grupos aderirem a discursos ora mais globais, ora mais locais. A quarta e última viria de necessidades organizacionais.

Essas quatro possibilidades geram, segundo Hegghammer, três formas de organizações híbridas: as historicamente locais, mas que aumentaram suas atuações contra alvos ocidentais; as globais, que progressivamente se viraram contra governos locais; e as nascidas híbridas - incluída na terceira a al Qa’idah do Iraque, protoversão do Estado Islâmico. ${ }^{38}$ Do ponto de vista teológico, o caráter híbrido de organizações salafistas (inclusive as jihadistas) foi analisado pelo historiador israelense Itzchak Weismann. Enquanto Hegghammer pensa a hibridização como a união de dois elementos minimamente delimitados, mas não puros, Weissmann, usa a palavra híbrido, mas opera com a noção de equilíbrio. $\mathrm{O}$ autor sugere que o relativo liberalismo dos salafistas de fins do século XIX e o purismo do salafismo no final do XX fez que pesquisadores, entre eles Witkorowicz, percebessem os dois movimentos como diferentes. $\mathrm{O}$ argumento do historiador é que, mesmo com divergências importantes, ambos compartilham a busca por um equilíbrio entre o islamismo ${ }^{39}$

38 Hegghammer, “The Ideological Hybridization of Jihadi Groups”.

39 Na língua portuguesa, o termo “islamismo” é usado como sinônimo de islã, contudo, nos estudos de jihad, significa um projeto de islamização social. Utilizaremos, 
radical e o conservadorismo salafista-wahhabita. ${ }^{40}$ Weismann afirma que os salafistas do século XIX, que se identificavam também como reformistas moderados, propunham uma forma islâmica de modernidade. Esses acadêmicos, concentrados em sua maioria no Cairo, sob influência britânica, defendiam uma orientação wahhabita da sociedade e a introdução de inovações ocidentais por meio da ijtihad, a racionalidade pautada nas escrituras sagradas. Após a Primeira Guerra Mundial e a formação de novos países nos antigos territórios otomanos, essas características teriam gerado uma cisão: de um lado os conservadores, aliados aos wahhabitas, do outro os mais ativos socialmente, que formaram organizações como a Irmandade Muçulmana. Weismann se alinha aos autores citados e defende o papel central da Guerra do Afeganistão para a união entre o wahhabismo (representado pelas gerações formadas por professores integrantes da Irmandade Muçulmana) e o islamismo radicalizado pelas ideias do poeta egípcio Sayyid Qutb (1906-1966). ${ }^{41}$ O historiador é perspicaz em sugerir que o equilíbrio se manifesta nos salafistas jihadistas contemporâneos a partir da noção de Hisbah: reforçar o bem e proibir o mal, segundo o autor, “a primeira [é] a essência da Irmandade Muçulmana, a última a marca do wahhabismo". ${ }^{42}$ A busca pelo equilíbrio mostra como igualar os Salafs é uma tarefa dificultada pela passagem do tempo. Uma vez que a experiência histórica dos muçulmanos ancestrais se afasta continuamente, salafistas se veem obrigados a deliberar sobre como proceder diante de questões

ao longo do texto, a segunda definição para islamismo.

40 Itzchak Weismann, “A Perverted Balance: Modern Salafism Between Reform and Jihad””, Die Welt des Islam, v. 57, n 1 (2017), pp. 33-66; Itzchak Weismann, "New and Old Perspectives in the Study of Salafism”, The Middle East Book Review, v. 8, n. 1 (2017), pp. 22-37.

41 Qutb se tornou sectário após retornar dos EUA, onde cursou mestrado entre 1948 e 1950. Encarcerado em 1954 pelo regime de Nasr, dedicou-se à redação do descomunal tafsir Fi zilal wal Qur'an (1964) e seu trabalho mais radical Milestones, publicado originalmente em 1965. Em Milestones, declarou que o mundo estava na jahiliyyah, tempo de ignorância anterior ao islã, e conclamou os muçulmanos à jihad. O teor incendiário do texto causou sua execução em agosto de 1966. John Calvert, Sayyid Qutb and the Origins of Radical Islam, Nova York: Oxford University Press, 2013; Larsson, “The Islamist Ideology of Hassan al-Banna and Sayyid Qutb”.

42 Weismann, “A Perverted Balance: Modern Salafism Between Reform and Jihad”, p. 57. 
contemporâneas: para tanto, torna-se necessário avaliar a situação no presente e definir qual momento histórico do início do islã será emulado.

Eventualmente, o recurso de estabelecer paralelos com as primeiras gerações para fundamentar decisões é inviável, e os salafistas tendem a recorrer a experiências posteriores. Esse processo é evidenciado em referências a acadêmicos como Ibn Taymiyyah. O comprometimento religioso do damasceno foi marcado pela centralidade dos Salafs, razão pela qual é reconhecido como Madhhab al-Salaf. Como se avaliará adiante, esse artifício pode gerar conflitos e pôr em questão a legalidade dos veredictos.

\section{Salafismos na era digital}

Especificamente, o Estado Islâmico não apresenta nenhuma referência aos salfistas do fim do século XIX. A organização se apresentava como seguidora rígida do islã original, praticado por Muhammad e seus primeiros seguidores, em oposição a manifestações posteriores da religiosidade. A pergunta então é: como um grupo arraigado numa leitura restrita de passado mobilizou com tanta destreza as inovações tecnológicas sem mover uma reflexão teológica? Duas respostas podem ser elencadas. A primeira está ligada à relação entre jihadismo e propaganda; a segunda aponta para o perfil dos sujeitos que integram organizações como o Estado Islâmico.

Assim como em outras partes do mundo, na região conhecida como Oriente Médio, a mídia teve papel relevante nas mudanças políticas e culturais. Os salafistas do século XIX, autoidentificados por assumirem uma postura de articulação entre a moralidade religiosa e a inovação tecnológica proveniente do Ocidente, apresentavam suas propostas por meio da revista al-Manar (O Farol), editada entre 1898 e 1935. Além disso, o nome Salafiyya vem da livraria homônima criada no Cairo em 
1909. ${ }^{43}$ A revista al-Jihad, editada por Abdallah 'Azzam durante a Guerra do Afeganistão (1979-1989), chegou a tiragens de 35 mil exemplares. ${ }^{44}$ De perspectiva secular, o regime de Jamal Abdel al-Nasir (1918-1970) investiu no desenvolvimento da radiodifusão como uma forma de se equiparar aos sermões oriundos das mesquitas. ${ }^{45} \mathrm{O}$ controle midiático desenvolvido a partir do nacionalismo estatal árabe dos anos de 1950 se manteve incólume até 1996, quando a rede al Jazeera foi fundada no Qatar. O efeito al Jazeera, segundo Phillip Seib, é resultado de formatos similares aos da CNN e BBC: amplo alcance nas principais cidades da região e com relativa independência do governo, características que causaram a ruptura com os monopólios midiáticos locais, apresentando narrativas globais. ${ }^{46}$ Dois anos mais tarde, em fevereiro de 1998, a Frente Islâmica Mundial lançou o fatwa Jihad Against Jews and Crusaders, assinado por Ibn Ladin e outras quatro lideranças jihadistas: al-Zawahiri (Grupo Jihadista no Egito), Abu-Yasir Rifa’i Ahmad Taha (1954-2016 - Grupo Islâmico Egípcio), Mir Hamzah (secretário do Grupo dos Ulamas do Paquistão) e Fazlur Rahman (Movimento Jihadista de Bangladesh). O fatwa acusa os EUA de ocupar as terras sagradas do islã e conspirar com Israel para destruir os muçulmanos. Como decreto, define a morte dos estadunidenses e seus aliados, militares ou civis, como uma obrigação para todos os fiéis. ${ }^{47}$ Em agosto de 1998, a al Qa'idah cumpriu a ordem e vitimou aproximadamente 224 pessoas em ataques a embaixadas na Tanzânia e no Quênia. A jihad, assim, abandonou as fronteiras nacionais e começou a se desenvolver em lugares outros até chegar a territórios ocidentais

43 Weismann, "New and Old Perspectives in the Study of Salafism".

44 Hegghammer, The Caravan.

45 Anour Abdel-Malez, “O renascimento do Egito” in J. F. Ade Ajayi, História geral da África, VI: África do século XIX à década de 1880 (Brasília: Unesco, 2010), pp. 377-410; Roberta Argoni Nogueira Vicenzi, "Nacionalismo árabe: apogeu e declínio”, Tese (Doutorado em Ciência Política), Universidade de São Paulo, 2006.

46 Phillip Seib, The Al Jazeera Effect: How the New Global Media are Reshaping World Politics, Nebraska: University of Nebraska Press, 2011.

47 Abu-Yasir Rifa’i Ahmad Taha, Ayman al-Zawahiri, Mir Hamzah, Fazlur Rahman e Usamah Ibn Ladin, "Jihad Against Jews and Crusaders: World Islamic Front Statement”, 23 fev. 1998 ש. 
em 2001 nos Estados Unidos, 2005 na Espanha, 2007 na Inglaterra e 2015 na França.

Além de alvos globais, a nova proposta também necessitava de alcance global. Segundo José Jorge Letria e Eric J. Hobsbawm, a mídia tem função vital para o terrorismo, ${ }^{48}$ seja para divulgar as teses de determinada organização ou sujeito, seja para ampliar a sensação de medo decorrente da violência. ${ }^{49}$ Após o 11 de setembro de 2001, a rede Al Jazeera enfrentou dilemas éticos e críticas internacionais por ter transmitido mensagens de Ibn Ladin enviadas por emissários da al Qa’idah. Se, em um primeiro momento, as gravações poderiam ser um ativo da emissora em relação à concorrência, os anos seguintes foram de críticas à forma de reportar a Guerra do Iraque, de transmitir os vídeos de Ibn Ladin e insinuações de relações promíscuas. ${ }^{50}$ Após os ataques em Londres, em julho de 2007, pressões internacionais obrigaram Al Jazeera a dificultar as tratativas com a al Qa'idah. ${ }^{51} \mathrm{~A}$ al Qa'idah não era dependente de Al Jazeera para espalhar sua mensagem, mas, dadas as suas ambições globais, a emissora propiciava, além do alcance, uma cobertura mais amena do que ofereciam (e oferecem) as mídias ocidentais. ${ }^{52}$ A Tawhid wal Jihad, liderada por

48 Em linhas gerais, existem dois usos correntes para o termo "terrorismo". O primeiro é político e, nesse sentido, são chamados de terroristas aqueles que praticam algum tipo de violência considerada ilegítima. Ver: Talal Assad, On Suicide Bombing, Nova York: Columbia University Press, 2008. A segunda define terrorismo como uma prática, um ato de violência que tem por objetivo causar medo e instabilidade. Arnaud Blin e Gérard Chailand, (orgs.), The History of Terrorism: from Antiquity to Al Qaeda, California: University of California, 2007. Neste artigo, avalia-se o projeto do Estado Islâmico como uma organização que utiliza métodos terroristas, mas é importante observar que se trata um meio, e não um fim.

49 José Jorge Letria, O terrorismo e os media: o tempo de antena do terror, Lisboa: Hugin, 2001. Eric J. Hobsbawm, Globalização, democracia e terrorismo, São Paulo: Companhia das Letras, 2007.

50 Rasha el-Ibiary, “Questioning the Al-Jazeera Effect: Analysis of Al-Qaeda’s Media Strategy and its Relationship with Al-Jazeera”, Global Media and Communication, v. 7, n. 3 (2011), pp. 199-204.

51 Jytte Klausen, “Tweeting the Jihad: Social Media Networks of Western Foreign Fighters in Syria and Iraq”, Studies in Conflict \& Terrorism, v. 38, n. 1 (2014), pp. 1-22.

52 Klausen, “Tweeting the Jihad”. 
Abu Musab al-Zarqawi, também figurou em alguns noticiários com uma diferença fundante: os vídeos eram interrompidos pouco antes das execuções. ${ }^{53}$

Jihadistas, via de regra, operam clandestinamente na difusão de sua propaganda, ${ }^{54}$ então os entraves impostos por Al Jazeera afetaram mais diretamente organizações ilustres como al Qa'idah. Foi a organização de Ibn Ladin que, no final de julho de 2010, construiu uma solução híbrida. A revista Inspire, de acordo com seu primeiro editorial, foi dedicada a “oferecer uma apresentação precisa do islã seguido pelos al Salaf al Salih”, com uma visão global, já que "no Ocidente; no leste, oeste e sul da África; no sul e sudeste da Ásia e em vários lugares há milhões de muçulmanos cuja primeira ou segunda língua é o inglês”. ${ }^{55}$ Ainda que recorresse ao expediente já conhecido de disseminar informações religiosas por meio da imprensa periódica, a Inspire indiciou inovações: era publicada em inglês, chancelada pela al Qa'idah e - mais importante - não tinha circulação restrita aos grupos locais (como foram as iniciativas citadas anteriormente), posto que pode ser acessada e lida por qualquer leitor interessado.

Dabiq não é uma sequência do projeto inaugurado por Inspire, tal afirmação exigiria maior tempo de estudo e fontes. Fundada pelo grupo Estado Islâmico, a revista faz parte das estratégias de disseminação global do programa jihadista. O Estado Islâmico foi uma organização jihadistas-salafista que logrou a conquista de territórios no Iraque e na Síria. Além

53 Napoleoni, Insurgent Iraq.

54 A propaganda jihadista pode influenciar a ação de lobos solitários - terroristas que atacam em seus países de origem - ou ensejar migração para zonas de conflito. Por essas razões, legislações são construídas com vistas a inibir o alcance desse tipo de material. O capítulo sobre ofensas terroristas do Counter-Terrorism and Border Security Act 2019, em vigência em todo território britânico, por exemplo, inclui uma seção específica sobre atividades na internet. O texto define que apenas jornalistas e pesquisadores podem ter acesso aos materiais sem o risco de sanções legais. Atualmente, os repositórios de fontes utilizados para esse artigo exigem credenciamento e têm normas específicas para download.

55 "Letter from the Editor”, Inspire: ... and Inspire the Believers, n. 130, jul. 2010 (1431 AH), p. 2, Inspire: Neurotmesis: Cutting the Nerves \& Isolating the Head, n. 13, 2014 (1436 AH). 
de arrogar-se como praticante do verdadeiro islã (conforme o profeta e os Salafs), a organização reclamou o legado de jihadistas contemporâneos como Abu Musab al Zarqawi e Usama Ibn Ladin.

Em termos de produção, o Estado Islâmico e a al Qa'idah têm estética similar aos padrões utilizados por periódicos ocidentais.

Figura 1

Capa da revista Inspire, n. 13, publicada em dezembro de 2014

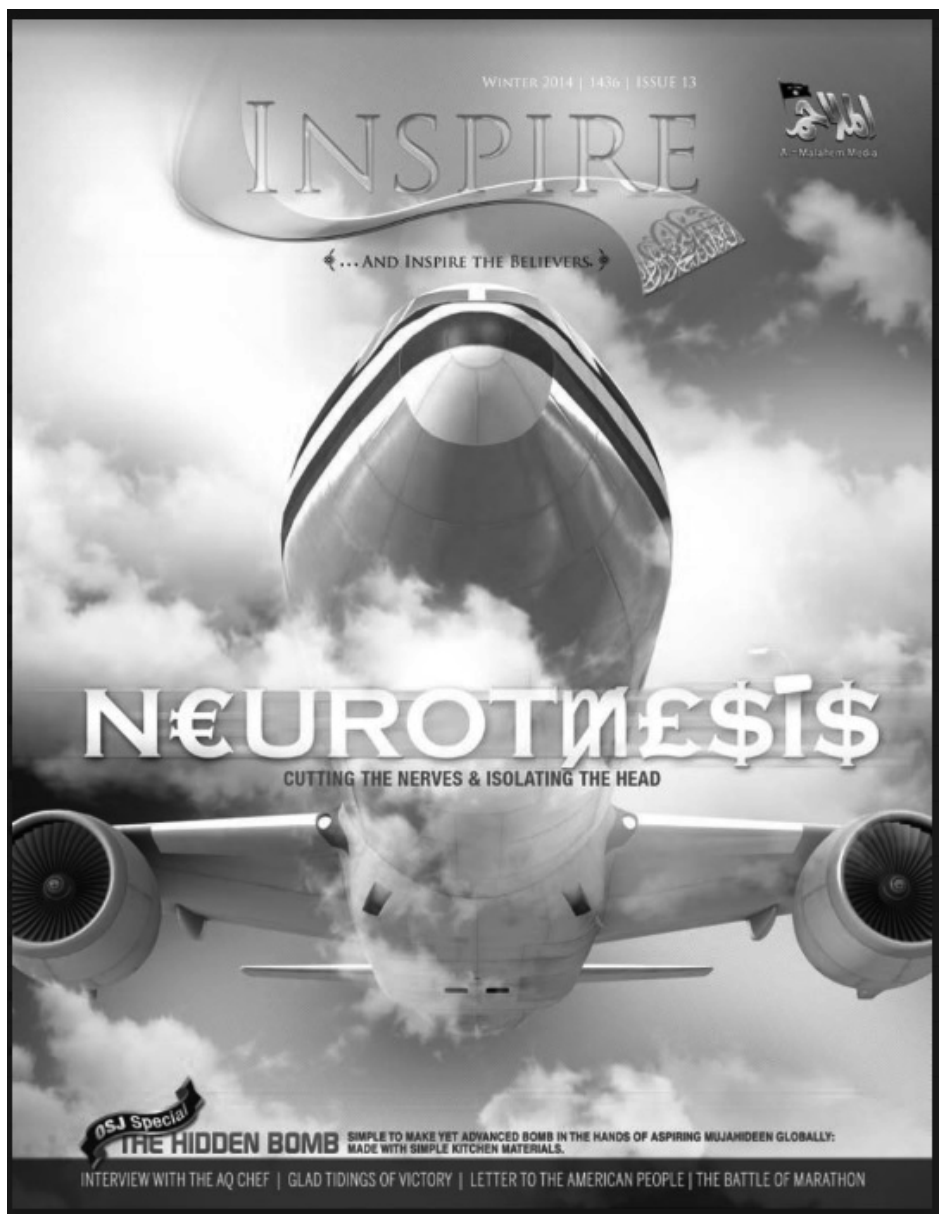


Figura 2

Capa da revista Dabiq, n. 6, publicada em dezembro de 2014

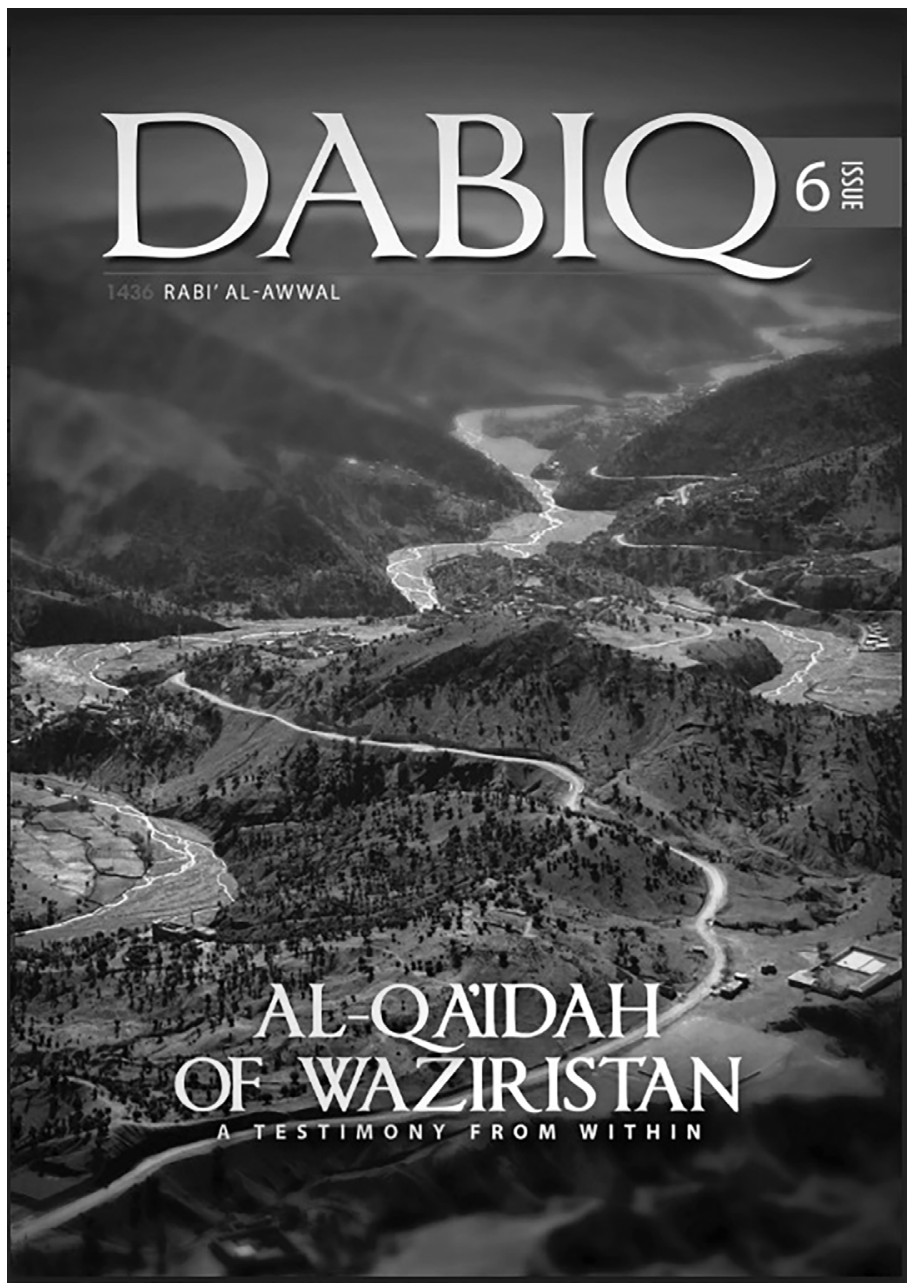

As duas imagens apresentadas são capas de Inspire e de Dabiq, lançadas em dezembro de 2014, das quais se destaca uma estrutura similar: uma imagem sobreposta pelos elementos textuais e gráficos. Contudo a produção da al Qa'idah apresenta mais elementos textuais dispostos em fontes, cores e tamanhos diferentes, indício de trabalho amador. No alto da 
página, os dados de produção em branco sobre um fundo também branco dificultam a leitura em determinados dispositivos. O termo Neurotmesis, ${ }^{56}$ no centro, que remete ao artigo principal, tem uma edição rudimentar na letra "i”, que fica ainda mais evidente na página de sumário; além disso, os ícones em dourado destoam do restante da arte, que prioriza o branco e o cinza.

Por sua vez, o Estado Islâmico optou por uma estética mais limpa dentro de uma paleta monocromática, por isso o ano "1436" é pouco visível. Os dois títulos, da revista e do artigo, têm a mesma fonte, e a mesma lógica se repete com os subtítulos. A comparação entre as capas aponta para uma característica das mídias do Estado Islâmico: a busca por organicidade na forma. Outro exemplo é o vídeo Healing of the Believers' Chests, de 2 de fevereiro de 2015, um dos mais conhecidos e acessíveis, já que ainda se encontra público no site da Fox News; na produção, o piloto jordaniano Muath al-Kasasbeh (1988-2015) é queimado vivo. ${ }^{57}$

O vídeo, contudo, é mais do que uma execução. São 22 minutos nos quais o rei da Jordânia, Abdullah II, foi acusado de trair os muçulmanos e apoiar os EUA. Há, ainda, uma entrevista com o piloto na qual ele contou parte de sua biografia, como eram os procedimentos e os armamentos utilizados nas missões de bombardeio, mencionou a boa relação com soldados americanos e, por fim, clamou aos inimigos do Estado Islâmico que se arrependam, reconhecendo que, para ele, não havia mais tempo ${ }^{58}$ Entre animações de aviões sobrevoando a Síria e o Iraque,

56 Em português, "neurotmese” significa um trauma no sistema nervoso. Em Inspire, refere-se à postura de decapitar os Estados Unidos destruindo a economia do país, chamada pelo periódico de "nervos da guerra americana". Inspire: Neurotmesis: Cutting the Nerves \& Isolating the Head, n. 13, 2014 (1436 AH).

57 Fundada em 1996, a Fox News é o principal meio de comunicação conservador dos Estados Unidos. A rede foi criticada por disponibilizar o vídeo, mas ainda o mantém em sua plataforma sob a justificativa de mostrar as atrocidades do islamismo. Gary B. Bunt, Hashtag Islam: How Cyber-Islamic Enviroments Are Transforming Religious Authority, North Carolina: The University of North Carolina Press, 2018.

58 “Healing of the Believers' Chests”, 3 fev. 2015, Al-Furqan Media (22 min). 
vê-se a destruição causada pelos bombardeios, corpos incinerados ou sob destroços. Em seguida, o refém caminha em ruas destruídas e cheias de escombros, a cena é interrompida algumas vezes por frames da destruição. Na sequência, o piloto aparece em uma jaula, coberto por um líquido. Uma tocha é atirada; ao fundo, pode-se ouvir um nasheed. No ato final, o corpo contraído é sobreposto por uma citação de Ibn Taymiyyah na qual se lê: "Se em um castigo exemplar público há o apelo aos incrédulos para que creiam ou que cessem a hostilidade, então é uma questão de cumprir os castigos prescritos e a jihad legal”. ${ }^{59}$ Em chamas, o corpo é coberto por entulho.

O vídeo Healing of the Believers' Chests pode ter rompido a barreira dos círculos jihadistas e dos pesquisadores pela particular forma de violência, mas reforça o cuidado que o grupo tem com suas produções. Em primeiro lugar, e por mais pavoroso que seja, o Estado Islâmico parece ter chegado à conclusão que decapitações já não eram agressivas o suficiente para se destacar naquilo que Susan Sontag chamou de "dieta de violência". ${ }^{60}$ Em consequência, a edição dos momentos derradeiros de forma fragmentada e com a sobreposição do áudio levanta a hipótese de que a organização tentou produzir materiais consumíveis por uma gama maior de público, diferentemente de seus mentores da Tawhid wal jihad.

Segundo, há uma preocupação com o roteiro da produção. Os vídeos à la Zarqawi, em que tudo ocorria em poucos minutos e de uma vez só, foram substituídos por diferentes recursos narrativos registrados em tempos e lugares diversos. O espectador não é informado sobre a justificativa da execução por meio da leitura de um documento, por vezes com captação de áudio rudimentar; ele é inserido na narrativa e acompanha Kasasbeh, o refém, em sua jornada final: da vida como soldado de um regime corrupto ao choque de realidade da captura,

59 “Healing of the Believers' Chests”, 19’00.

60 Susan Sontag, Diante da dor dos outros, São Paulo: Companhia das Letras, 2003. 
da confrontação dos pecados representados pelas suas ações à punição por seus atos.

Segundo Gary Bunt, a qualidade de edição e diagramação dos produtos da organização variam a partir do público-alvo, o que não inviabiliza diversas produções midiáticas. ${ }^{61}$ Aaron Zelin, pesquisador e coordenador do blog Jihadology, identificou que, em abril de 2015, em sete dias, o Estado Islâmico publicou 123 itens de mídia diferentes, incluindo números do jornal al-Naba', folhetos, fotos, vídeos e transmissões na sua própria rádio, a al-Bayan. ${ }^{62}$ Charlie Winter evidenciou um aparato midiático complexo comandado pelo grupo: com seis grandes produtoras, objetivos diferentes, e ligadas com outras 35 produtoras locais. ${ }^{63}$ Al Hayat, produtora de Dabiq, tinha como objetivo disseminar, em línguas estrangeiras, as visões do grupo para públicos mais variados e esteve ligada diretamente ao comando do Estado Islâmico ${ }^{64}$ Além disso, a produtora (sobre a qual pouco se sabe), selecionava quais conteúdos oriundos de centros midiáticos menores deveriam ser traduzidos e publicizados. Por exemplo, a entrevista com Kasasbeh foi publicada em dezembro de 2014, na edição de número 6 de Dabiq, como um prólogo ao vídeo. Em fevereiro do ano seguinte, Dabiq número 7 abordou diretamente o vídeo, respondendo às críticas que o Estado Islâmico recebeu pelo modo como ocorreu a morte do piloto. Mais à frente, o conteúdo desse debate será abordado, mas, por ora, cabe ressaltar que o grupo produziu muito, em quantidade e em qualidade.

Um dos objetivos centrais de Dabiq foi a Hijrah, ou migração. ${ }^{65}$ Anunciada como foco já no primeiro editorial, a Hijrah perpassou todos

61 Bunt, Hashtag Islam.

62 Aaron Zelin, “Picture or it Didn’t Happen: A Snapshot of the Islamic State’s Official Media Output, Perspectives on Terrorism, v. 9, n. 4 (2015) ש.

63 Charlie Winter, Virtual "Caliphate": Understanding the Islamic State's Media Strategy, Londres: Quiliam, 2015.

64 Winter, Virtual "Caliphate”.

65 Marius Steindal, "ISIS Totalitarian Ideology and Discourse: an Analysis of Dabiq Magazine Discourse”, Dissertação (Mestrado em Ciências Sociais), Norwegian University of Oslo, 2015. 
os números do periódico e foi tema exclusivo de 12 dos 284 textos publicados, incluindo a capa da edição de setembro de 2014. É inviável precisar o número de combatentes estrangeiros que se juntaram ao Estado Islâmico e, por extensão, a influência do periódico na tomada dessa decisão, mas algumas estimativas ajudam a dimensionar.

O ingresso de combatentes estrangeiros às causas do islã pode ser identificado a partir da Guerra dos Seis Dias (1967). Durante os múltiplos conflitos no Afeganistão, entre 1979 e 2001, e as guerras da Bósnia (19921995) e do Iraque (2003), estima-se que o número de migrantes para zonas de conflito foi de dez a trinta mil. ${ }^{66}$ Entre 2011 e 2014, após a Primavera Árabe, segundo Hororo Ingram de vinte a trinta mil estrangeiros chegaram à Síria e ao Iraque para se juntar aos jihadistas. ${ }^{67}$ Ainda a respeito da Síria e do Iraque, Tanya Mehra apontou, a partir dos arquivos da Europol, que em 2015 o número de combatentes passou de três para cinco mil sujeitos oriundos de cerca de sessenta países. No final de 2016, a autora estimava quinze mil estrangeiros na região. ${ }^{68}$ Dabiq apresentou vários relatos de migrações bem-sucedidas, a exemplo da seção Among the Believers are Men, surgida no sétimo número. ${ }^{69}$ Além disso, considerando a proclamação do califado, a Hijrah foi defendida como uma obrigação desde o segundo editorial da revista. ${ }^{70}$ Há, na narrativa do periódico, um apelo moral e de salvação por meio da migração. O número 3 de Dabiq afirmou que viver entre os infiéis mata o coração de um muçulmano. No ocidente, o horário das orações foi solapado pelo relógio, ${ }^{71}$ o sistema de ensino corrompeu a

66 Thomas Hegghammer, "The Rise of Muslim Foreign Fighters: Islam and the Globalization of Jihad”, Quarterly Journal: International Security, v. 3, n. 3 (2010), pp. 53-94.

67 Hororo Ingram, “An Analysis of Islamic State’s Dabiq Magazine”, Australian Journal of Political Science, v. 51, n. 3 (2016), pp. 458-477.

68 Tanya Mehra, "Foreign Terrorist Fighters: Trends, Dynamics and Policy Responses”, The International Centre for Counter-Terrorism - The Hague, v. 3, n. 7 (2016), pp. 1-32.

69 Dabiq: From Hypocrisy to Apostasy: The Extinction of Grayzone, n. 7, 2015 (Rabi` Al-Hakhir 1436 AH) ש.

70 “Foreword”, Dabiq: The Flood, n. 2, jul. 2014 (1435 AH).

71 “Modern Day Slavery”, Dabiq: A Call to Hijrah, n. 3, 10 set. 2014 (Shawwal 1435 AH). 
juventude e excluiu deus de sua obra, ${ }^{72}$ a estrutura familiar foi destruída por meio liberação de práticas heréticas. ${ }^{73}$ Em suma, não é possível manter a fé em terras infiéis. Por isso, na revista, o grupo se apresentou como responsável por um Estado funcional e atraente para os fiéis do mundo todo, com infraestrutura, ${ }^{74}$ economia, ${ }^{75}$ saúde e educação; ${ }^{76}$ organizados em acordo com os preceitos do islã.

Argumentos como esse têm apelo, notadamente, entre gerações de filhos e netos de imigrantes que habitam regiões em que são minoria. De acordo com Alain Badiou, são justamente esses grupos os mais afetados pelas dificuldades de acesso à políticas públicas que facilitem a integração social. A consequência desse processo é, segundo o autor, a associação de certos estratos dessas comunidades a atividades ilegais. ${ }^{77}$ Conforme Zygmunt Bauman, situações como essa são utilizadas por diversos governos ocidentais como fundamento para a criação de zonas de segregação dos estranhos que, supostamente, ameaçam a segurança interna. ${ }^{78}$ Como consequência, em suas reflexões sobre a crise migratória de 2015, Bauman concluiu que as políticas que visavam restringir a entrada de imigrantes favoreciam a narrativa de grupos extremistas como o Estado Islâmico. ${ }^{79}$ Ressalte-se que as democracias liberais do ocidente, ao mesmo

72 Abu Thabit al-Hijazi, "O You Who Have Believed, Protect Yourselves and Your Families from Fire”, Dabiq: Just Terror, n. 12, 18 nov. 2015 (1437 AH).

73 “The Fitrah of Mankind and the Near-Extinction of Western Woman”, Dabiq: Break the Cross, n. 15, 31 jul. 2016 (Shawwal 1437 AH).

74 “A Window into the Islamic State”, Dabiq: The Failed Crusade, n. 4, 11 out. 2014 (Dhul-Hijjah $1435 \mathrm{AH}$ ).

75 “The Currency of the Khilafah”, Dabiq: Remaining and Expanding, n. 5, 21 nov. 2014 (Muharram 1436 AH); John Cantlie, "Meltdown”, Dabiq: Al-Qa'idah of Waziristan: a Testimony from Within, n. 6, 29 dez. 2014 (1436 AH).

76 "Healthcare in the Khilafah", Dabiq: They Plot and Allah Plots, n. 9, 21 maio 2015 (Sha'ban $1436 \mathrm{AH}$ ).

77 Alain Badiou, Notre Mal Vient de Plus Loin: Penser les Tueries du 13 Novembre, Paris: Fayard, 2016.

78 Zygmunt Bauman, Comunidade: a busca por segurança no mundo atual, Rio de Janeiro: Zahar, 2003.

79 Em 2015, com o aumento do fluxo migratório de sírios nas praias europeias, a União Europeia se propôs a buscar uma solução coletiva, por meio da qual o asilo seria dividido entre as nações associadas. Contudo representantes e forças políticas 
tempo em que defendem a pluralidade, operam concessões ou passam o verniz da tolerância em práticas discriminatórias. ${ }^{80}$ Autores como Homi Bhaba associam a emergência de fundamentalismos religiosos a uma ânsia por identidade, que rememora o tempo e reclama territórios perdidos. ${ }^{81}$ As reflexões do filósofo indiano permitem afirmar que, no islã, o salafismo procura suprir essa necessidade.

Gary Bunt afirma que a internet transformou as práticas comunitárias e ritualísticas do islã e, por extensão, favoreceu a divulgação de material jihadista. Teria surgido, dessa forma, a $e$-jihad, termo que faz referência ao engajamento digital de grupos e indivíduos à prática jihadista. ${ }^{82}$ Em Hashtag Islam, o autor inclui o Estado Islâmico em suas análises e observa que a produção midiática do grupo resulta da influência e existência de milhares de jovens fluentes digitais. Tais sujeitos mesclam tecnologias ou referenciais digitais de seu cotidiano à tradição religiosa: leem o Qur'an e Ibn Taymiyyah em computadores e celulares, e, pela web, disseminam e se apropriam do islamismo. ${ }^{83}$ Compreender esse processo é fundamental para tornar a jihad inteligível, afinal, como esclarece Stuart Hall, a relação de grupos culturais com o mundo que os cerca

Tem a ver não tanto com as questões "quem nós somos" ou "de onde nós viemos”, mas muito mais com as questões "quem nós podemos

nacionais mobilizaram narrativas excludentes a fim de impedir ou inibir a entrada de imigrantes. Entre as posições mais agressivas, destacam-se as dos presidentes da República Tcheca, Miloš Zeman, e da Hungria, Viktor Orbán. O primeiro acusou refugiados de utilizar crianças como escudo, o segundo afirmou que todo terrorista é migrante; ver: Zygmunt Bauman, Estranhos à nossa porta, Rio de Janeiro: Zahar, 2017.

80 Judith Butler, Quadros de Guerra: Quando a vida é passível de luto? Rio de Janeiro: Civilização Brasileira, 2015.

81 Homi Bhabha, “O entrelugar das culturas” in Eduardo F. Coutinho (org.), O bazar global e o clube dos cavalheiros ingleses: textos seletos, (Rio de Janeiro: Rocco, 2011).

82 Gary B. Bunt, IMuslims: Rewiring the House of Islam, North Carolina: The University of North Carolina Press, 2009.

83 Gary B. Bunt, Hashtag Islam. 
nos tornar", "como nós temos sido representados" e "como essa representação afeta a forma como nós podemos representar a nós próprios”. Elas têm tanto a ver com a invenção da tradição quanto com a própria tradição, a qual elas nos obrigam a ler não como uma incessante reiteração, mas como "o mesmo que se transforma". ${ }^{84}$

Dabiq foi, nesse sentido, um meio de arregimentação muito eficiente. As fontes consideradas autênticas pelos salafistas foram produzidas séculos antes do renascimento da jihad no Afeganistão. Distantes no tempo, tais documentos se tornam igualmente inacessíveis quando as traduções estão indisponíveis ou a linguagem é diversa daquela com a qual os agentes contemporâneos estão familiarizados. Por seu turno, a revista Dabiq se apresentava com diagramação ordinária, fazia longas citações do Qur'an, Ahadiths e de intelectuais muçulmanos em línguas acessíveis ao público ocidental (como francês e o inglês), as quais eram atualizadas graças a intervenções pontuais que conectavam o passado ao presente.

O idioma em Dabiq, inclusive, merece atenção. A revista não foi publicada integralmente em inglês: aproximadamente cem termos foram apenas transliterados, como, por exemplo, jihad, Allah e Hijrah. Além desses, cuja grafia original não surpreende, conceitos religiosos como da 'wah, kufr e murtadd não deram lugar, respectivamente, aos homólogos: pregação, infiéis e infidelidade de modo geral, e apóstata. O mesmo se pode dizer de certas regiões como Cáucaso, Coração e Levante, que foram chamados de Qawqaz, Khurasan e Sham.

Em um periódico cuja própria existência indicava a abertura cultural estratégica do grupo quando as finalidades políticas exigiam novas

84 Pouco antes, no mesmo texto, o autor afirmou: "Precisamos vincular as discussões sobre identidade a todos aqueles projetos e práticas que têm perturbado o caráter relativamente "estabelecido" de muitas populações e culturas: os processos de globalização [...] e os processos de migração forçada (ou 'livre')”, Stuart Hall, "Quem precisa de identidade?” in Tomaz Tadeu da Silva (org.), Identidade e diferença: a perspectiva dos estudos culturais (Petrópolis: Vozes, 2014), pp. 108-109. 
abordagens, tais manutenções linguísticas são sinais da criatividade característica dos processos de hibridação. Dessa forma, ainda que utilizassem uma língua moderna associada ao expansionismo cultural norte-americano, não deixavam de marcar, linguisticamente, uma identidade religiosa. O que poderia ser lido como incoerência deve ser visto como uma tática de engajamento político.

Para concluir, na mesma linha de Bunt, Jytte Klausen, aponta que jihadistas que migraram para as zonas de guerra mantêm os mesmos comportamentos on-line que os usuários no Ocidente. A autora identificou os vestígios digitais desses sujeitos que recorrem a textos e imagens corriqueiros nas redes sociais, mas que se singularizam pelo conteúdo jihadista. ${ }^{85}$ É o que se pode observar na foto apresentada na Figura 3, publicada com a intenção de mostrar que a vida no Califado não é cheia de restrições.

Na imagem, o jihadista Abu Muthanna, kunya de Nasser Ahmed Muthana, um britânico que atuou no Estado Islâmico como recrutador on-line, aparece junto a uma metralhadora e com a barba sem aparar. ${ }^{86}$ Essas características são indícios de sua atuação na jihad. Ao mesmo tempo, a camiseta da Adidas, o pote de creme de avelã Nutella e a foto no Twitter são indícios da hibridação. A ironia, ao menos para o público brasileiro, é que o termo "Nutella” é utilizado nas redes sociais para se referir às gerações que supostamente perderam a essência, ao contrário da "geração raiz", formada por pessoas autênticas e que conheceram um passado melhor que o presente.

85 Klausen, “Tweeting the jihad”.

86 Kunyas são nomes de guerra utilizados por jihadistas, principalmente após a Guerra do Afeganistão. A estrutura segue uma lógica Abu (pai de) Muthana (geralmente o nome do primogênito) al-Yemini (local de onde o jihadista veio ou deseja ser associado); Klausen, “Tweeting the Jihad”. 
Figura 3

Jihadista do Estado Islâmico posa com um pote de creme de avelã

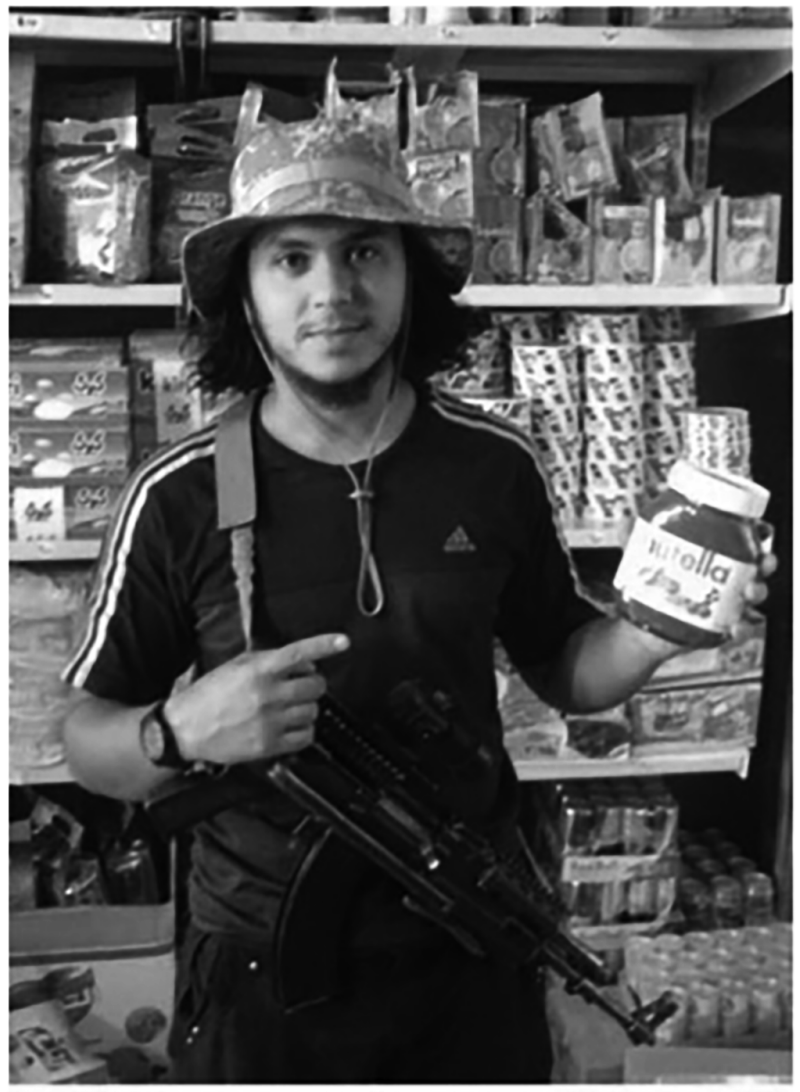

Guy Van Vierden eGuyVanViorden - Jun 19

French $\pi$ ISIS fighter Abou Mouthana proudiy showing the Nutella he has found in AN-Bab, $=$ Syria. pic.twitter.com/usP2inScrW

4 Reply ea Retweor ^ Favorite

Flag modia

Fonte: Jytte Klausen, "Tweeting the Jihad: Social Media Networks of Western Foreign Fighters in Syria and Iraq”, Studies in Conflict \& Terrorism, v. 38, n. 1 (2014), p. 12.

Os elementos abordados anteriormente demonstram que, quer por necessidades imediatas quer pela presença de combatentes estrangeiros, 
o salafismo se modificou progressivamente na medida em que os meios digitais foram assumidos como recursos da jihad. Essa mudança aconteceu de forma lenta, o que amortizou o impacto na maioria das organizações jihadistas e tornou reflexões teológicas prescindíveis. Contudo, em alguns casos, as práticas adotadas foram consideradas inventivas e, por isso, incompatíveis com o salafismo e, por conseguinte, com o islã. O assassinato de Muath al-Kasasbeh foi, nesse sentido, emblemático.

\section{Salafismos e as disputas pelas Sunnahs}

No início de fevereiro de 2015, quando o vídeo Healing of the Believers’ Chests já havia impactado o mundo, a rede de TV jordaniana Roya transmitiu um programa especial intitulado Muath, Shahid al-Haq (Muath, o verdadeiro mártir), no qual foi entrevistado Abu Muhammad al-Maqdisi. ${ }^{87}$ O peso simbólico da entrevista pode ser aquilatado pelo itinerário do personagem, afinal, trata-se de um dos principais teóricos jihadistas desde os anos 1990, que mantém uma relação histórica com o Estado Islâmico.

Sabe-se que o Estado Islâmico se colocou como herdeiro de Abu Musab al-Zarqawi, sendo uma frase do jihadista a epígrafe de todos os números de Dabiq. Segundo consta, o jordaniano de Zarqa teve uma juventude conturbada até se reconectar com sua fé e, em 1989, partir para o Afeganistão em busca de jihad. Pouco mais tarde, em 1992, al-Zarqawi voltou à Jordânia, onde acabou preso por conspirar contra a monarquia Hashimita, em 1994. O tempo na prisão foi integrado à biografia do personagem como um período de aprendizado, ${ }^{88}$ fundamental ao desen-

87 Abu Muhammad al-Maqdisi, Entrevista a Mohammad Al Khalidi (Muath, Shahid al-Haq/Al Roya TV), Amann, 6 fev. 2015 ש 2.

88 As prisões são consideradas espaços férteis para a jihad, uma vez que, encarcerados, diversos sujeitos encontram forças na fé e dispõem de tempo para aprender mais sobre o tema. Além de al-Zarqawi, o líder do Estado Islâmico, Abu Bakr al-Baghdadi, também emergiu como liderança após dez meses preso no Camp Bucca, no Iraque, em 2004. A relação entre presídios e jihad foi mais detidamente abordada em Patrick 
volvimento de um pensamento islamista e marcado pela influência de Abu Muhammad al-Maqdisi, que foi seu colega de cela até a libertação de ambos em 1999. ${ }^{89}$ Durante a entrevista, al-Maqdisi afirmou que tentou contatar as lideranças do Estado Islâmico logo após a captura de Muath, o piloto assassinado no vídeo. O objetivo, segundo al-Maqdisi, era convencer o grupo a negociar com o governo jordaniano a soltura do militar em troca da liberdade de Sajida al-Rishawi (1970-2015) e Ziad al-Karbouly (1970-2015), jihadistas presos dez anos antes. ${ }^{90}$ Na sequência, al-Maqdisi alegou ter sido enganado por representantes de um califado falso, preocupados apenas em agredir. Para o jordaniano, o Estado Islâmico deturpou a imagem do movimento jihadista e salafista, uma vez que, segundo ele, o objetivo central de um califado seria proteger os muçulmanos, e não dividir; instruir, e não destruir.

É importante observar que al-Maqdisi, um crítico do governo jordaniano, não considerava Kasasbeh inocente, mas discordou frontalmente do tipo de castigo aplicado. A Shar 'iah, conjunto de recomendações que estruturam a justiça islâmica, não são um regramento estático, afinal, à luz do islã, uma mesma prática pode ser considerada ingênua, equivocada ou ilegal e, portanto, as punições podem variar. Além disso, o status de ilegalidade de uma prática pode ser revisto por um conselho de acadêmicos. ${ }^{91}$ A crítica de al-Maqdisi se desenvolve em três partes. Primeiro,

Dunleavy, The Fertile Soil of Jihad: Terrorism's Prison Connection, Nebraska: University of Nebraska Press, 2011.

89 Napoleoni, Insurgent Iraq.

90 Al-Rishawi foi presa pela justiça jordaniana em 2005, após seu cinto explosivo não detonar durante operações conduzidas pela al Qa'idah do Iraque. Al-Karbouly foi encarcerado também na Jordânia no ano seguinte, 2006, sob acusações de ser assistente de Abu Musab al Zarqawi. É interessante observar que Maqdisi não explora a relação estreita entre Zarqawi, al-Rishawi e al-Karbouly e Estado Islâmico, para exigir um grau maior de comprometimento por parte do autoproclamado califado. A hipótese mais plausível é o histórico desentendimento entre o teórico e o seu "aluno" mais afamado. Para entender os posicionamentos de Maqdisi, ver: Joas Wagemakers, "Defining the Enemy: Abu Muhammad al-Maqdisi Radical Reading of Surat al-Mumtahana”, Die Welt des Islam, v. 48, n. 3, (2008), pp. 348-371.

91 Etim Okon, "Hudud Punishments in Islamic Criminal Law”, European Scientific Journal, v. 10, n. 14 (2014), pp. 227-238. 
o Estado Islâmico distorceu relatos sobre o profeta a fim de promover o assassinato de inimigos. O teórico afirmou que, em diversas ocasiões, Muhammad perdoou e só reagiu violentamente em contextos específicos. Em seguida, al-Maqdisi evocou a narrativa da coleção de Ahadiths Sahih al-Bukhari, na qual o profeta definiu que a punição com fogo é reservada ao Senhor do Fogo, Allah. Por fim, o teórico criticou o uso da citação de Ibn Taymiyyah, alegando que o Qur'an e o Hadith são claros o suficiente e têm precedência sobre a posição do acadêmico. Ademais, o papel de um jurista, para o jordaniano, não é permitir ou proibir, mas avaliar, quando necessário, a solução mais viável. Essas considerações, segundo al-Maqdisi, evidenciaram que o Estado Islâmico não seguia a Sunnah (tradição), mas criava novas Sunnahs (tradições) para justificar as atitudes da própria organização. O jihadista encerra afirmando que o Estado Islâmico, ao seguir Ibn Taymiyyah, e não a Sunnah do profeta, demonstra que não é realmente salafista. ${ }^{92}$

No mesmo dia em que Maqdisi foi entrevistado, o historiador britânico Jon Hoover, um dos principais especialistas em Ibn Taymiyyah, publicou um artigo no jornal eletrônico The Conversation. No texto, Hoover pontuou que o excerto no final do vídeo não tem relação com a resistência antimongol..$^{93}$ Para o autor, o argumento de Ibn Taymiyyah, quando examinado mais atentamente, é uma crítica à vingança, estabelecendo que o uso do castigo físico será permitido se resultar na conversão

92 Nos termos de Stuart Hall: "Possuir uma identidade cultural nesse sentido é estar primordialmente em contato com o núcleo imutável e atemporal, ligando ao passado o futuro e o presente numa linha ininterrupta. Esse cordão umbilical é o que chamamos de 'tradição', cujo teste é o de sua fidelidade às origens, sua presença consciente diante de si mesma, sua ‘autenticidade'. É, claro, um mito - com todo o potencial real dos nossos mitos dominantes de moldar nossos imaginários, influenciar nossas ações, conferir significado às nossas vidas e dar sentido à nossa história”, Stuart Hall, "Pensando a diáspora: reflexões sobre a terra no exterior", in Da diáspora: identidades e mediações culturais (Belo Horizonte: Editora UFMG, 2003), p. 29.

93 A conversão para o islã de Mahmud Ghazan em 1295 fazia de Ibn Taymiyyah um opositor de um governo muçulmano. Salafistas jihadistas no século XX voltaram aos fatwas emitidos pelo acadêmico para, como ele, excomungar e autorizar o combate contra seus governantes. 
dos infiéis ou no cessar de hostilidades. ${ }^{94} \mathrm{Na}$ mesma linha, al-Maqdisi questionava em tom de ironia se o Estado Islâmico acreditava que o assassinato de Kasasbeh interromperia os bombardeios. Hoover afirmou que Ibn Taymiyyah foi citado apenas para adicionar prestígio à narrativa do Estado Islâmico e concluiu que, nesse sentido, o vídeo não deveria ser visto como um ato impensado de violência, mas como estratégia de intervenção política. Ficava a dúvida se o objetivo da produção foi a paz ou a conversão. ${ }^{95}$ Em Dabiq 7, também de fevereiro de 2015, o tema foi abordado em um breve artigo de quatro páginas. Embora "The Burning of the Murtadd Pilot" não tenha citado diretamente as críticas feitas por al-Maqdisi, identificado em nota de rodapé como representante dos tiranos jordanianos, é perceptível que o artigo estabelece um debate com as considerações expostas na entrevista. O texto iniciava com alegações de que o Estado Islâmico fez todo o possível para libertar al-Rishawi e al-Karbouly, cuja execução, após o fracasso das negociações, os tornava mártires, algo que há muito ansiavam. ${ }^{96}$ Em seguida, o artigo atacava os que criticaram a forma da execução; aos "ignorantes" esclarecia a fundamentação das ações do grupo: um versículo do Qur'an, no qual o texto sagrado sugere que, ao decidir punir, deve-se punir com a mesma força. ${ }^{97}$ Entretanto o periódico transcreveu apenas metade do ayat (versículo) que, na versão integral, aconselha a paciência. Observe-se que os dois versículos seguintes, os finais da Surat An-Nahl, sugerem que deus levará em conta a piedade. ${ }^{98}$ Na sequência do artigo, foram elencadas cinco narrativas sobre os atos dos Salafs nas quais a punição

94 Jon Hoover, "How to Read the Medieval Scholar the Islamic State Used to Justify al-Kasasbeh Murder”, The Converstarion ש.

95 Hoover, "How to Read the Medieval Scholar the Islamic State Used".

96 "The Burning of the Murtadd Pilot", Dabiq: From Hypocrisy to Apostasy: the Extinction of Grayzone, n. 7, 12 fev. 2015 (1436 AH).

97 Para uma introdução à noção de justiça nas sociedades do chamado Oriente Médio, ver: Norman Yofee, Mitos do Estado arcaico, São Paulo, Edusp, 2013; sobretudo, o capítulo IV, “Quando a complexidade foi simplificada”.

98 Gilvan Figueiredo Gomes, ““Até queimar os exércitos cruzados’: projetos políticos do Estado Islâmico na revista Dabiq (2014-2016)”, Dissertação (Mestrado em História), Universidade do Estado de Santa Catarina, Florianópolis, 2019. 
com fogo foi aplicada, para concluir que o Estado Islâmico seguia os passos do profeta e de seus companheiros quando adotava as mesmas práticas. O propósito era, como antes, aterrorizar os apóstatas e fazer deles exemplos. ${ }^{99}$

Maqdisi, citado em rodapé, sem surpresas foi acusado de estar em uma "campanha de mentiras". Tratava-se de comportamento recorrente no periódico que enaltecia jihadistas mortos (como Ibn Ladin e al-Zarqawi) e atacava os vivos, caso de al-Maqdisi e Ayman Zawahiri. Tal expediente reforça a hipótese de que havia disputas de memória. Essa disposição fica ainda mais evidente no tratamento dispensado a Mula Omar, líder do Taliban, que, após o anúncio de sua morte em 2015, se tornou ameno.

É interessante observar que Ibn Taymiyyah não é citado no artigo. É difícil saber a efetividade das críticas de al-Maqdisi e de outros salafistas que se opuseram ao modelo de justiça adotado pelo Estado Islâmico, mas a escolha de referências utilizadas por Dabiq (como o Qur'an e os atos dos Salafs) para justificar a forma (não o assassinato), levanta a hipótese de desconforto. Como se abordou anteriormente, os salafistas reconhecem como autênticas um número reduzido de fontes e recorrem a acadêmicos mais recentes somente em casos extremos. Nesse caso, a aplicação atípica da Shar'iah exigiria fundamentações a partir das mesmas fontes.

Faria sentido, assim, a crítica de Maqdisi quando afirmou que o Estado Islâmico inventava suas próprias Sunnahs, tradições? Dentro de um movimento que se pretende tão purista como salafismo, tratava-se de grave constatação. E, ao optar por citar Ibn Taymiyyah no vídeo, um acadêmico do século XIII, em vez de um verso do Qur'an (posição que jamais seria contestada), percebem-se os níveis de hibridação do Estado Islâmico, disposto a barganhar com o passado quando lhes convém. Afinal, a passagem do tempo exige negociações.

99 “The Burning of the Murtadd Pilot”. 
O salafismo se transformou ao longo do século XX. Joas Wagemakers mostrou como o leitmotiv do pensamento de al-Maqdisi (liderança do movimento no fim do século XX), a noção de Wala wal Bara - "lealdade ao que deus ama e repúdio ao que deus abomina" - tem origem no movimento Kharejita, uma seita radical originada no fim do califado de Ali em 655. ${ }^{100}$ Peter Demant defende que a noção de jahiliyyah - tempo de ignorância anterior ao islã -, caracterizada por Qutb como um estado de espírito, não se refere a um corte cronológico, de forma que pode incidir sobre os fiéis em diferentes momentos. ${ }^{101}$ Essa proposição abre possibilidades para interpretar o recurso a Ibn Taymiyyah, pois, no segundo parágrafo do primeiro capítulo de Milestones, Qutb afirma que, no período da revelação do islã, houve a melhor geração de seres humanos, mas faz uma ressalva de que sujeitos com as mesmas qualidades existiram em tempos posteriores. ${ }^{102}$ Essa consideração sugere que Ibn Taymiyyah, largamente citado por Qutb e pelo Estado Islâmico, seria um Salaf.

O que a análise das mídias do Estado Islâmico e dos usos das referências religiosas consideradas autênticas aponta é um processo de reconversão. As tecnologias e principalmente a internet assumem traços híbridos quando combinadas a uma mensagem salafista, que utiliza os recursos digitais para a pregação islamista. O Qur'an, os Ahadith e a produção dos Madhhab al-Salaf são mobilizadas para fundamentar práticas necessárias no presente e com vistas ao futuro. Reconverter a tecnologia e as fontes de conhecimento islâmico possibilita ao salafismo hibridizar essas duas estruturas e, desse modo, entrar e sair do passado em busca do islã puro, perfeito e útil. Conforme avalia Homi Bhabha, diante de tais objetos, "encontramo-nos no momento de trânsito, em que espaço e tempo se cruzam para produzir figuras complexas de

100 Joas Wagemakers, “The Transformation of a Radical Concept: al-Wala wa-l-Bara in the Ideology of Abu Muhammad al-Maqdisi” in Roel Meijer (org.), Global Salafism: Islam's New Religious Movement, (London: Hurst, 2009), pp. 81-106.

101 Demant, O mundo muçulmano.

102 Sayyid Qutb, Milestones, Birmingham: Maktabah Booksellers Publishers, 2006. 
diferença e identidade, passado e presente, interior e exterior, inclusão e exclusão". ${ }^{103}$

\section{Considerações finais}

Observou-se que o Estado Islâmico não pode ser compreendido a partir de recursos interpretativos tradicionais, cujas limitações podem torná-lo um projeto marcado pela irracionalidade, ausência de estratégia política, postura estática, entre outros. Sua complexidade reside no fato de que abandona uma racionalidade usual, pois não se trata de uma manifestação cultural baseada na ideia de coerência aos moldes ocidentais. Sua atuação cultural inventiva não se presta a uma localização precisa: passado ou presente, religioso ou laico, tradicional ou moderno não são categorias utilizadas como orientação para a atividade do grupo.

Longe de uma reificação do passado, o fôlego político do grupo provém de uma relação criativa com o passado e com o presente. Como parte do salafismo, é preciso ter em conta que o Estado Islâmico é resultado e continuação de uma ideia de jihadismo que emergiu ao longo do século XX, após processos de hibridação que responderam a diferentes demandas. Exigências do colonialismo, de governos locais ou a invasão de terras muçulmanas fizeram que esses fiéis reconvertessem o islã em uma doutrina sectária, ganhando contornos violentos. Apesar dessas transformações, o grupo se considerou o único praticante do islã.

Como organização, todas as encarnações do Estado Islâmico foram fundadas no século XXI. As inovações tecnológicas desse século permitiram a diferentes grupos ampliar o alcance de suas narrativas: no caso da internet sem os filtros das mídias formalmente estabelecidas. Dabiq e Healing of the Believers' Chests são, nesse sentido, modelares para evidenciar que tais inovações também foram reconvertidas em favor do

103 Homi Bhabha, O local da cultura, Belo Horizonte: Editora UFMG, 1998, p. 19. 
islã. Essas produções têm conteúdo declaradamente salafistas e formatos identificados com a modernidade.

Hegghammer, ao analisar a dicotomia global-local no movimento jihadista após a Guerra do Iraque, afirmou, ainda que indiretamente, que o Estado Islâmico nasceu híbrido. ${ }^{104}$ Weisman identificou, nos salafismos dos séculos XIX e XX, a busca por equilíbrio entre o engajamento público e o purismo religioso. ${ }^{105}$ Este artigo buscou examinar como processos de hibridização garantiram o equilíbrio entre salafismo e inovação tecnológica. Tais interstícios - tomados como sobreposição e deslocamento de domínios de diferença ${ }^{106}$ e a interculturalidade - vista como fusão precária - ${ }^{107}$ permitiriam investigar as ações e atuações culturais do Estado Islâmico tendo em vista suas próprias significações. Ademais, foi possível apreender o movimento em sua complexidade sem caracterizá-lo a partir do vocabulário reduzido do terrorismo.

Recebido em 20 jun. 2020

Aprovado em 15 jan. 2021

doi: 10.9771/aa.v0i63.37411

104 Hegghammer, “The Ideological Hybridization of Jihadi Groups”.

105 Weismann, “A Perverted Balance”.

106 Bhaba, O local da cultura.

107 Nestor Garcia Canclini, Diferentes, desiguais e desconectados: Mapas da Interculturalidade, Rio de Janeiro: Editora UFRJ, 2009. 
A pesquisa toma como objeto de análise a relação entre os grupos salafistas e as dinâmicas culturais que lhe são contemporâneas. Especificamente, avalia-se o Estado Islâmico, grupo salafista-jihadista que emergiu como protagonista de debates políticos e religiosos a partir de 2014. Com base nos recursos teóricos e metodológicos dos estudos culturais, as intervenções midiáticas do grupo são interpretadas como indícios de hibridização entre posicionamentos tradicionais e suportes modernos. Sinais de criatividade e de mobilidade cultural, as condutas do grupo foram importante estratégia de recrutamento. A competência da organização em operar essas duas estruturas fez do Estado Islâmico o grupo jihadista mais bem-sucedido da segunda década do século XXI.

Estado Islâmico | Hibridização | Salafismo

\section{INVENTING A SUNNAH:}

\section{the IsLamic State, SALAFism and InNovation}

This study analyzes the relationship between different Salafi groups and the contemporary cultural dynamic surrounding them. Specifically, the paper assesses the role of the Islamic State, a Salafi-jihadi group that emerged in 2014 as a leader in political and religious debates. Utilizing the theoretical and methodological resources of cultural studies, the paper analyzes the group's media interventions, viewing them as evidence of hybridization between traditional positions and modern supports. Signalling creativity and cultural mobility, the group's conduct was an important recruitment strategy. The organization's competence in operating these two structures has made Islamic State the most successful jihadi group of the second decade of the 21st century.

Islamic State | Hybridization | Salafism 